\title{
Review:
}

\section{Tropical Tannin for Engineering Application}

\author{
Nor Adzwa Binti Rosli ${ }^{1}$, Wan Asma Ibrahim ${ }^{2}$, Zulkafli Hassan ${ }^{1, *}$, and Azizul Helmi Bin Sofian ${ }^{1}$ \\ ${ }^{1}$ Faculty of Chemical and Natural Resources Engineering, Universiti Malaysia Pahang, \\ Lebuhraya Tun Razak 26300, Gambang, Pahang, Malaysia \\ ${ }^{2}$ Forest Research Institute Malaysia (FRIM), 52109 Kepong, Selangor Darul Ehsan, Malaysia
}

\begin{abstract}
*Corresponding author:
email:zulkafli@ump.edu.my

Received: August 3, 2018

Accepted: December 11, 2018

DOI: $10.22146 / \mathrm{ijc} .40877$

Abstract: In this study, some approaches have been proposed to establish an alternative and option of brand-new compounds by using green sources that can minimize the environmental threat in the engineering application industry. Tannin, a chemical component extracted from plant origin, has the potential to bind with proteins and other polymers. The description of tannin can be amplified to cover a complete mass of constituents which give typical phenolic reactions, and hence, it has the properties to interact with the aqueous solution. The potential of tannin to associate allows its usability in the oil and gas industry. The aim of this review in this particular context will be emphasized the use of tannin in the implementation of drilling fluid, mercury removal, wastewater treatment, and corrosion inhibitor.
\end{abstract}

Keywords: tannin; corrosion inhibition; drilling fluid; mercury; wastewater

\section{- INTRODUCTION}

Tannins in actuality are a substantial and diverse family of the phenolic compound with different structure and widely distributed through the plant kingdom. It has myriad supplemental roles in a plant's life cycle, as protective tissue and defense strategies [1]. The phenolic compound is consist of a hydroxyl group $(-\mathrm{OH})$ bonded to an aromatic compound and has the properties to interact with the aqueous solution. The phenolic compound is an active compound from the lower bond separation energies of -OH group and not difficult to lose $\mathrm{H}$ atom [2]. Hence, tannin-containing enough hydroxyl group to encouraging effective cross-linking of other compounds. Phenol which contains - $\mathrm{OH}$ group attached to a hydrocarbon is a type of weak acid, and even if it is still a weak acid, phenol is sufficiently recognizably acidic properties. A hydrogen base ion can transfer to a base when it breaks away from the -OH group.

The essential property of tannin is its ability to combine with proteins and other polymers [3]. Tannin mostly found in the tree bark, galls, legumes, fruits, and vegetable, and it has the crucial property which is to combine with proteins and other polymers. Thus, it promotes its consumption in a variety of industry such as in medicine, leather processing, dye industry, ink manufacture, and especially in engineering industries. Tannin has chemical properties such as precipitation, anti-oxidant, astringent, carcinogenicity, and reaction with salts. They have a dark brown or reddish brown color and the puckering taste. In the market, tannin can be found in powder and liquid form. It is soluble in water, alcohol, dilute alkali, glycerol, and acetone [4].

Older than the Amazon jungle and around 130 million years old ago, Malaysia's rainforests take part in some of the most various tropical ecosystems in the world. Through the Ice Age, Southeast Asia's rainforests pursue to encounter moist temperatures because of its geographical position and place. Furthermore, it allowed them to evolve much advanced than the tropical rainforests of South America and Africa. In Malaysia, there is an entire of 112 tropical mangrove forest reserves and form a segment of the country's Permanent Forest Estate which is supervised for sustainable forestry manufacture. The roots of the mangrove tree carry a 
massive load of tannins, and in the soil solution, it interacts with ferric ion causing in the blackening of the roots as the tannin-ferric iron complex formed. Tannin can be extracted from mangroves species of the family Rhizophoraceae, which are particularly favored for making charcoal as it claimed by some to produce the best charcoal in the world [5]. The abundance of studies and productions used mangrove trees to yield tannin due to the high-quality content compared to the non-tropical tannin that extracts from other sources like a mimosa, chestnut, or quebracho trees. Studies have proven that the rich content of raw tannins up to $29 \%(\mathrm{w} / \mathrm{w})$ could be extracted from the mangrove bark based on the 3-day solid-liquid extraction with $70 \%(\mathrm{v} / \mathrm{v})$ aqueous acetone. Mangrove bark is inexpensive and copious available. The extraction of tannins from the mangrove bark requires simple and economical methods; hence, they are of significant commercial value.

Tannin commonly is separated into significant groups, i.e., condensed tannin, and hydrolyzable tannin. Hydrolyzable tannins can deteriorate in water, with which they react to make different substances, produce various water-soluble manufacture and products, such as gallic acid, sugars protocatechuic acid. Gallotannin, or usual tannic acid, is the finest known of the hydrolyzable tannins. The center of a hydrolyzable tannin contains a carbohydrate. The carbohydrate that contains hydroxyl groups can be classified as entirely esterified with phenolic acids gallic or partially. Hydrolyzable tannins able hydrolyzed by weak bases of weak acids to create phenolic acids and carbohydrate. Condensed tannins, recognized as proanthocyanidins, are broadly disseminated in plants and greatly influence the standard of foods. About 2-50 (or more) flavonoid units of polymers, which are not capable of hydrolysis. Some tannins which are under the group of hydrolyzable and few condensed tannins are soluble in water while massive condensed tannins are indissoluble or insoluble [6].

\section{- APPLICATIONS OF TANNIN}

\section{Binding Activity of Tannin}

This section explains the general chemical properties of tannin in binding with certain substances. Tannins supply hemostatic properties and astringent to a compound. They intercommunicate and interact with carbohydrates, proteins (enzyme), polysaccharides, and cell membranes of bacteria. When tannin reacts with carbohydrates, the greater the molecular weight of the carbohydrate, the more it gets across with tannins. For bonding to take place between protein and tannin, protein needs to have an open and flexible structure, a large molecular size, and to be loaded in proline. Hence, tannin requires a high molecular weight and free structures. The mechanism of bonding happens when hydrophobic and hydrogen joining hydrolyzable tannins and proanthocyanins from tannin-protein complexes in comparative ways. These groups are extremely steady structures and are exceptionally not easy for the gut to separate. It is workable for proteins to interact with tannins when the measure of protein is in overabundance or excess of that of the tannin. At the point when this happens, there is no precipitation, and it is hard to see whether the reaction has occurred. Insoluble complexes will be formed when the measure of tannins surpasses that of protein, and a hydrophobic external layer is framed [7]. The hydroxyl groups are incredible at building hydrogen bonds with proteins; the hydrophobic type of the benzene rings interface particularly firmly with proline residues in proteins; and in light of the fact that a single tannin molecule is so expansive, it can gather numerous proteins together, making the entire mass precipitated. By the facts, tannins are believed to have strong ability and tendency to bind with chemical substances, and it has been used in various usability in engineering applications.

\section{Tannin in General Engineering Applications}

Tannin is a vital additive in the manufacture of tanning leather. Tanbark from mimosa, oak, quebracho

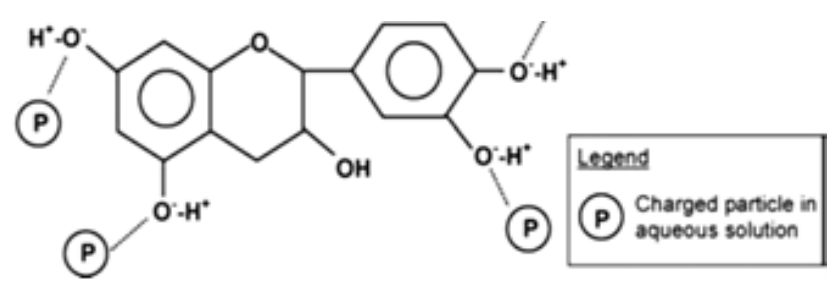

Fig 1. Representation of basic tannin structure in aqueous solution and possible molecular interaction [8] 
tree, and chestnut has commonly been the main deviation of tannery tannin; nevertheless, inorganic tanning agents were also used in nowadays and consumed the world's leather manufacture for 90\% [9]. Tannin or tannic acid contributes to the application in the dye industry, water purification, ink manufacture, surface coatings, plastic resins, production of adhesives, drilling fluid, removal of mercury, wastewater treatment, manufacture of gallic acid, etc. [3]. Table 1 summarizes the analysis of the usage of tannin in numerous applications by the researchers. Besides, it has been more than four decades in which tannin used to shelter and fortify steam boilers by notable levels above ASME direction. By using tannin from the green foundation as corrosion inhibitors, it minimizes the water and energy consumption, contaminants in effluent wastewaters, greenhouse gases discharge, and even decreasing the environmental mark of industrial operations [10].

\section{Tannin as Corrosion Inhibitor}

Corrosion activity is accountable for abundant losses, especially in the industrial sector. Among the diverse methods to prevent or avoid the destruction of the metal surface, the corrosion inhibitor is one of the better methods of corrosion protection and one of the most contribution in the industry. This method is considered to be good due to practice method and low cost. Crucial researches have been conducted with government investment specifically in large areas such as evolution construction of new pipelines for growth and shale gas in construction. The attention of these researches has been the inhibitors utilization in water and concrete for the protection of metals [12]. Several papers have submitted and described the use of natural products in the growth of productive environmental corrosion inhibitors for dissimilar metals in different systems. Tannins are group of non-toxic biodegradable organic compounds, and also a polyphenol that can be built from the source of bark trees such as mimosa, quebracho, chestnut, and mangrove [13]. In the previous study, the corrosion activity in inhibited hydrochloric acid of mild steel electrodes is narrated. Typical weight loss evaluation reveals that the greatest concentration of $140 \mathrm{ppm}$ of tannin from Rhizophora racemosa is needed to get a percentage of $72 \%$ corrosion inhibition. Natural atmospheric exposure research displayed that specimens interact in phosphoric acid $\mathrm{H}_{3} \mathrm{PO}_{4}$, an inorganic corrosion inhibitor withstand corrosion for three weeks, and while tannin treated specimens effected with corrosion attack of experiment nearest to one week [14]. Table 2 shows the study of the different type of tannin from mangrove species as inhibitor used in corrosion test with specific specimens used in the experiment.

Fig. 2 explains the efficiency of phosphoric acid, tannin/phosphoric acid and tannin respectively in $1 \mathrm{M}$ hydrochloric acid $(\mathrm{HCl})$, where it is noticed that tannin presented the greatest efficiency at $140 \mathrm{ppm}$ of $72 \%$ at a concentration while efficiencies of about 61 and 55\% were resulted by tannin/ $/ \mathrm{H}_{3} \mathrm{PO}_{4}$ and $\mathrm{H}_{3} \mathrm{PO}_{4}$ respectively at

Table 1. Analysis of the use of tannin in general engineering application

\begin{tabular}{llr}
\hline \multicolumn{1}{c}{ Use of tannin } & Engineering Application & Reference \\
\hline $\begin{array}{l}\text { Manufacture of gallic acid, ink manufacture, dye } \\
\text { industry, surface coatings }\end{array}$ & Chemical, material & {$[11]$} \\
$\begin{array}{l}\text { Possible l sources of new natural drugs, insecticides, } \\
\text { herbicides, and antibiotics }\end{array}$ & Medical, environmental & {$[1]$} \\
Dyes, perfumes, fibers, flavoring agents, glues, oils & The material, mechanical, aromatic & {$[1]$} \\
Corrosion inhibitor & Material, mechanical & {$[12-20]$} \\
Removal of mercury & Wastewater, environmental & {$[21-29]$} \\
Coagulant in water treatment & Wastewater, environmental & {$[30-33]$} \\
Thinner in drilling fluid & Oil and gas & {$[34-36]$} \\
Resin & Material, mechanical & {$[37-40]$} \\
\hline
\end{tabular}


Table 2. Analysis of the different type of tannin as inhibitor used in corrosion test

\begin{tabular}{llc}
\hline Inhibitor & Specimen & Reference \\
\hline Tannin Takaot galls (Tamarix articulata) & Copper & {$[13]$} \\
Tannin bark Melaleuca cajuputi Powell (Gelam) & Mild Steel & {$[15]$} \\
Tannin Rhizophora apiculata mangrove bark & Mild steel & {$[16]$} \\
Tannin Rhizophora apiculata mangrove bark & Mild Steel & {$[17]$} \\
Tannin Rhizophora racemosa & Mild Steel & {$[14]$} \\
Tannin Rhizophora apiculata mangrove bark & Steel & {$[18]$} \\
Black wattle tannin & Carbon Steel & {$[19]$} \\
Modified nonionic tannic acid & Carbon Steel & {$[20]$} \\
\hline
\end{tabular}

the same concentration. Tannin and tannin $/ \mathrm{H}_{3} \mathrm{PO}_{4}$, efficiencies increased with greater in concentration or, in other words with the discoveries of different analysts who utilized natural based compounds as inhibitors for mild steel in different concentrations [41]. Fig. 3 shows the graph of $\%$ inhibition efficiency (IE) in the addition of mangrove tannin (MT). The graph shows the addition of \% IE from 0.1 to $1.0 \mathrm{~g} / \mathrm{L}$ MT followed by a gradual increase from 1.0 to $3.0 \mathrm{~g} / \mathrm{L}$ MT and the IE in the presence of MT increased up to $72.8 \%$ at $3 \mathrm{~g} / \mathrm{L}$ [13]. Tannin also applied in the seawater solution, and it illustrates the trend of increasing inhibition efficiency as tannin content became greater in the paint, as demonstrated in Fig. 4 with $83.86 \%$ at a higher amount of tannin (6 g) [16]. As represented in Fig. 5, tannin extracted from Melaleuca cajuputi Powell (gelam) added in the acidic medium shows increasing inhibition efficiency from 6 to $40.77 \%$ when the concentration of inhibitor increases from 0 to $300 \mathrm{ppm}$ [15].

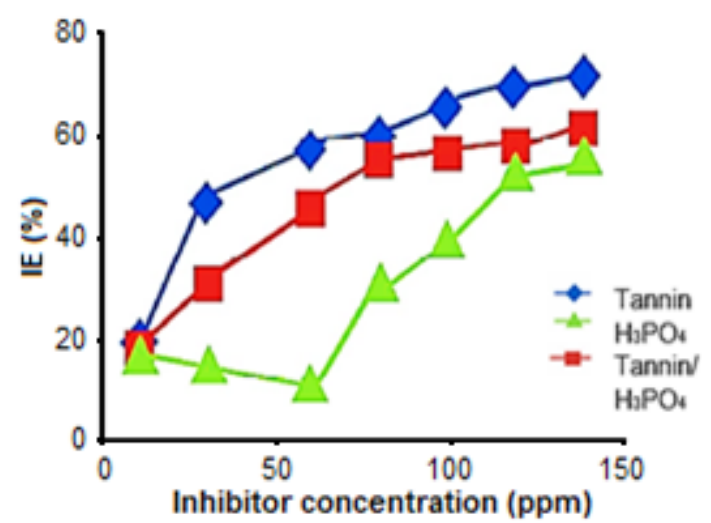

Fig 2. The corrosion of mild steel in $1 \mathrm{M} \mathrm{HCl}$ for the efficiency of various inhibitors on at $30^{\circ} \mathrm{C}$ [14]

\section{Use of Tannin as Natural Coagulant for Water Treatment}

Coagulation is a chemical pre-treatment activity planned to take out colloidal substances in charge of turbidity. The sedimentation trouble of colloidal particles under the process of their own responsibility is because of the electrical charges of equal sign they bring, which disseminate repulsion among the particles by means of electrostatic forces [30]. These electrical charges are partially or totally neutralized upon coagulation. Hence, under gravitational forces, the particles can get at the same instant giving rise to great agglomerates, the flakes, which drain automatically. Most of the coagulant used in conventional treatment involves inorganic coagulants that may synthetic or plant origin as it aspiring of significant environmentally friendly behavior and natural low cost. At a recent time, a tannin-based coagulant used in water purification for

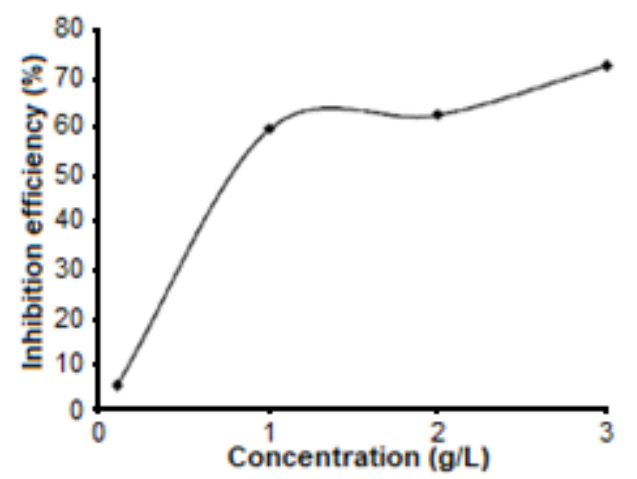

Fig 3. Graph of inhibition efficiency of $0.5 \mathrm{M}$ hydrochloric acid with a different concentration of tannin in the presence of mangrove tannin [13] 


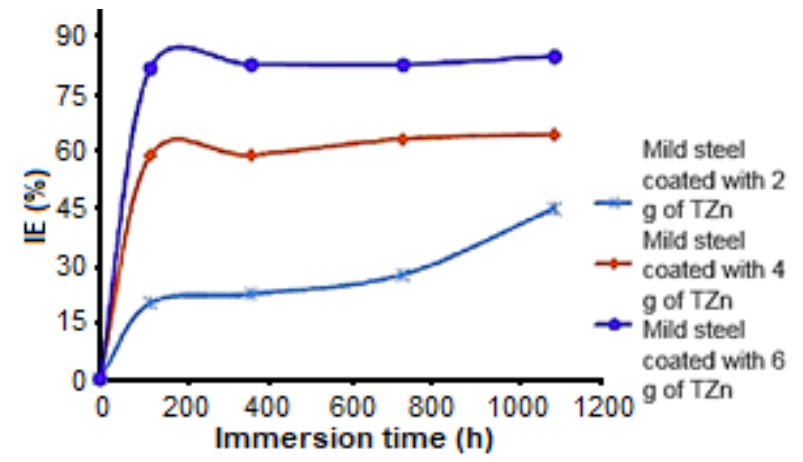

Fig 4. Inhibition efficiency of zinc tannate (TZn) at different amount during immersion in $3.1 \mathrm{wt} . \%$ solution in $2160 \mathrm{~h} \mathrm{[17]}$

flocculation processes. Tannin promotes amphoteric nature from the phenolic groups and does not undergo hydrolysis in solution; hence, its operational as a coagulant is consistently optimal. The benefit of tannin demonstrated as it does not change the $\mathrm{pH}$ of the suspension and the formation of flakes. The irregular shape supplies large surface contact, which magnifies the efficiency of flocculation [31]. The activity of tannin with aminoethanol and formaldehyde build a weakly, basic polymer that is extra successful than alum in discard turbidity and mainly color from river water. Özacar and Şengil [32] deliberate the outcome of tannin on the filterability of sludge established in the coagulation reaction and resulted that the formed sludge could be filtered as a coagulant when tannin was used. Diverse experiments that have been led on water treatment coagulant using the tannins have shown that the effectiveness of tannins is contingent on especially on the compound structure of tannins that have been extricated from the plant and degree of tannin alteration [33].

\section{Tannin in Drilling Fluid Performance}

In the process of water-based muds and drilling fluids, the thinning agent is significant to reduce the viscosity and plays a role in regulating rheological properties. These greatly effectual products avoid the need for mud dilution, which also needs replenishment of mud chemicals and grows mud volume and disposal costs. The function of thinner will preserve disseminated drilling fluid rheology; hence, securing against mud gelling or flocculation due to contamination and or high

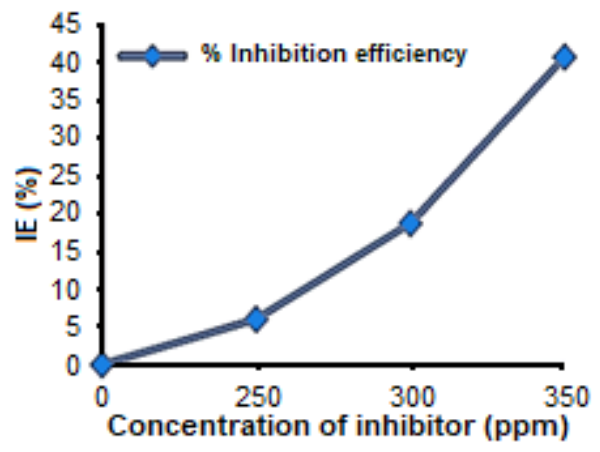

Fig 5. Inhibition efficiency of mangrove tannin in $1 \mathrm{M}$ hydrochloric acid with a different concentration of tannin in the presence [15]

temperature. A thin filter-cake at the wellbore evaded associated issues, and excess fluid can be achieved in the present and help of thinners [34]. Tannins have the mechanism in which it works by thinning the clays, where the positive edges of the clay platelets are adsorbing. The reaction creates to repulsion among the platelets and plugging action of the particles themselves. The role of tannin as additive enhances the handling of solids inside the drilling fluid by deflocculating solids like bentonite and between the colloidal nature of the chemical, skewing the particle size dispersal to lower valves [35]. In a study, a chrome-free drilling mud thinner known as tin-tannin-lignosulfonate (TTLS) has been productively formulated by crosslinking tannin with lignosulfonate acid in addition of formaldehyde and stannous ions. As a result, it shows a great prospect to be commercialized from the striking performance of TTLS as a water-based drilling mud thinner. Furthermore, it is a good tolerance to salt contamination and favorable tolerance to temperature [36].

\section{Removal of Mercury from Solution by Tannin Adsorbent}

In industrial chemicals, most of the electrical and electronic application manufactured by mercury, one of the heavy metal elements that is toxic to the environment. Some other instances in an industry that consumes mercury in their process are cement industry, mining, nuclear energy production, steel production, and corrosive paints [21]. There had been issues where the waste of heavy metal are not appropriately arranged 
when they are disposed of to the environment. The global development trend towards gradually of mercury-added products will come out in the generation of excess mercury if mercury provides the stand and remain at the current level. For that reason, an environmentally sound organization and management of mercury wastes will be a serious issue for nearly all countries. During previous years, there was sprouting engrossment the use of biomaterials for the preconcentration with sorption of heavy metals from water. Plant extraction as bark, algae, roots, and leaves was used to this occasion. To be specific, the waste of wood industry comes from the bark has the ability source for the recuperation of heavy metals, as it carries a huge amount of vegetable tannin [22]. The ability of tannin to forms chelates with metals because of the hydroxyl groups in its molecule become attention in studies adsorption of mercury and methylmercury in solutions. The hydroxyls are the fundamental of useful gatherings exist in tannin molecules, and the adsorption of cations in tannin resin can be clarified by the metal chelation with adjoining hydroxyl groups of the tannin phenolic molecules. [23]. Table 3 synopsize different methods and tannin sources in the process of removing mercury in solutions.

A study on $\mathrm{Hg}(\mathrm{II})$ removal from aqueous solution by bayberry tannin-immobilized collagen fiber (BCITCF) had been proved that the adsorption of BCITCF follows the chelating process activity. The BCITCF can be simply produced with $0.1 \mathrm{M}$ lactic acid following adsorption operation and recycled no less than 4 times without the loss of adsorption capacity. To sum up, the BCITCF can be utilized as a beneficial adsorbent for productive removal of mercury from aqueous solution [24].

Table 3. Analysis of the methods of removing mercury and heavy metal by tannin

\begin{tabular}{|c|c|c|}
\hline Type of tannin & Methods & References \\
\hline $\begin{array}{l}\text { Removal of mercury(II) and } \\
\text { methylmercury from solution by tannin } \\
\text { adsorbents }\end{array}$ & $\begin{array}{l}\text { Adsorbent synthesis of tannin resin } \\
\text { process from Eucalyptus saligna Sm (ETS) } \\
\text { and Lysiilona latisiliqua (LTS) in removing } \\
\text { mercury (II) and methylmercury }\end{array}$ & {$[25]$} \\
\hline $\begin{array}{l}\text { Removal of cadmium and mercury ions } \\
\text { from aqueous solution by sorption on } \\
\text { treated Pinus pinaster bark: kinetics and } \\
\text { isotherms }\end{array}$ & $\begin{array}{l}\text { Formaldehyde pre-treated Pinus pinaster } \\
\text { bark was used to absorb } \mathrm{Hg}^{2+} \text { and } \mathrm{Cd}^{2+} \\
\text { from aqueous solutions }\end{array}$ & {$[26]$} \\
\hline $\begin{array}{l}\text { Hg(II) removal from aqueous solution by } \\
\text { bayberry tannin-immobilized collagen } \\
\text { fiber }\end{array}$ & $\begin{array}{l}\text { Adsorption process used by immobilizing } \\
\text { barberry tannin (BT) onto collagen fiber } \\
\text { was found to be effective to eliminate } \\
\text { mercury }\end{array}$ & {$[24]$} \\
\hline $\begin{array}{l}\text { Biosorption of } \mathrm{Pb}(\mathrm{II}) \text { ions by modified } \\
\text { quebracho tannin resin }\end{array}$ & $\begin{array}{l}\text { Fourier transform infrared spectroscopy } \\
\text { (FTIR), and Scanning electron microscopy } \\
\text { (SEM) was used to study quebracho tannin } \\
\text { resin on the adsorption of lead }\end{array}$ & {$[27]$} \\
\hline $\begin{array}{l}\text { Synthesis and characterization of tannin- } \\
\text { immobilized hydrotalcite as a potential } \\
\text { adsorbent of heavy metal ions in effluent } \\
\text { treatments }\end{array}$ & $\begin{array}{l}\text { An adsorbent in the removal of heavy } \\
\text { metal ions by immobilizing tannin of } \\
\text { modification of calcined hydrotalcite } \\
\text { (HTC) }\end{array}$ & {$[28]$} \\
\hline $\begin{array}{l}\text { Removal of mercury from wastewater use } \\
\text { of green adsorbents - a review }\end{array}$ & $\begin{array}{l}\text { Compilation of method used such as } \\
\text { chemical precipitation, conventional } \\
\text { coagulation, adsorption, ion exchange and } \\
\text { reverse osmosis in the removal operation } \\
\text { of mercury }\end{array}$ & [29] \\
\hline
\end{tabular}




\section{- CONCLUSION}

This review shows that the study on tannin for engineering applications have attracted the attention of more researchers. The nature and composition of tannin prove that the binding capability can be amplified to enhance the wastewater treatment, removing the heavy metal in the solution, refine and enhance drilling fluid operation and reduce the risk of corrosion in plant processing. Tannins have a good potential as an effective flocculating agent to be used as a natural coagulant for its ability to get rid of turbidity. Besides, the practical application of tannin as an adsorbent can be expected for the removal of mercury for its excellent desorption and adsorption behavior, highly effective, reusable adsorbent, and low cost.

Furthermore, in order to maintain a system in drilling fluid performance with the condition of a dispersed (deflocculated) state, the repulsive forces must be maximized. One of the ways to maximize the negative charges of the clay particles is by adding deflocculant and tannin had become the common chemical where it can be effective at low concentration. Local tannin as a natural inhibitor can replace the synthetic inhibitor since it acts as cathodic on a tested specimen based on studies of corrosion testing. By proving the use of tannin, conclusively tropical tannin that can be extracted from mangrove trees specifically can promote tannin as one of the vital chemical substances in engineering implementation and yet providing more job opportunities to those exceptionally living in mangrove areas.

\section{- REFERENCES}

[1] Rana, M.S., Tyagi, A., Hossain, S.A., and Tyagi, A.K., 2012, Effect of tanniniferous Terminalia chebula extract on rumen biohydrogenation, $\Delta^{9}$-desaturase activity, CLA content and fatty acid composition in Longissimus dorsi muscle of kids, Meat Sci., 90 (3), 558-563.

[2] Bendary, E., Francis, R.R., Ali, H.M.G., Sarwat, M.I., and El Hady, S., 2013, Antioxidant and structureactivity relationships (SARs) of some phenolic and anilines compounds, Ann. Agric. Sci., 58 (2), 173-181.
[3] Ramakrishnan, K., and Krishnan, M.R.V., 1994, Tannin - Classification, analysis, and applications, Anc. Sci. Life, 13 (3-4), 232-238.

[4] Kushwaha, R., Rai, S.N., Singh, A.K., Chandra, G., Vaidya, M.M., Sharma, V.K., Pathan, M.M., and Kumar, S., 2007, Tanniniferous feed resources in dairy animals: A review, Agric. Rev., 32 (4), 267-275.

[5] Rahim, A.A., 2005, Physico-Chemical Characterisation of Mangrove Tannins as Corrosion Inhibitors, Dissertation, Universiti Sains Malaysia.

[6] Izawa, K., Amino, Y., Kohmura, M., Ueda, Y., and Kuroda, M., 2010, "Human-Environment Interaction - Taste", in Comprehensive Natural Products II: Chemistry and Biology, Volume 4, Eds. Mander, L., and Liu, H.W., Elsevier Science, 631-671.

[7] Aldred, E., 2009, Pharmacology, A Handbook for Complementary Healthcare Professionals $1^{\text {st }}$ Ed., Churchill Livingstone, 149.

[8] Vijayaraghavan, G., Sivakumar, T., and Kumar, A.V., 2011, Application of plant-based coagulants for waste, IJAERS, 1 (1), 88-92.

[9] Gupta, A.K, 2008, Tannin Based Wood Adhesive, Niir Project Consultancy Products: Nirr Project Consultancy Services, New Delhi, India, 56-59.

[10] Dargahi, M., Olsson, A.L.J., Tufenkji, N., and Gaudreault, R., 2015, Green technology: Tanninbased corrosion inhibitor for protection of mild steel, Corrosion, 71 (11), 1321-1329.

[11] Wheatley, M.J., 2001, "Use of Tannins Adhesives Applications, Industrial Problems and Potentials" in Plant Polyphenols, Springer, Boston, USA, 1005-1011.

[12] Dariva, C.G., and Galio, A.F., 2014, "Corrosion Inhibitors-Principles, Mechanisms and Applications" in Development in Corrosion Protection, IntechOpen, London, 365-376.

[13] Shah, A.M., Rahim, A.A., Hamid, S.A., and Yahya, S., 2013, Green inhibitors for copper corrosion by mangrove tannin, Int. J. Electrochem. Sci., 8, 21402153.

[14] Oki, M., Charles, E., Alaka, C., and Oki, T.K., 2011, Corrosion inhibition of mild steel in hydrochloric acid by tannins from Rhizophora racemosa, Mater. 
Sci. Appl., 2, 592-595.

[15] Talib, N.A.A., Zakaria, S., Hua, C.C., and Othman, N.K., 2014, Tannin bark Melalauca cajuputi Powell (gelam) as green corrosion inhibitor of mild steel, AIP Conf. Proc., 1416, 171-177.

[16] Idora, M.S.N., Quen, L.K., and Kang, H.S., 2017, Effect of tannin from Rhizophora apiculate as corrosion inhibitor for epoxy paint on mild steel, $J$. Phys. Conf. Ser., 890, 012062.

[17] Nik, W.B.W., Jahar, H.M., Idora, M.S.N., Suriani, M.J., and Yabuki, A., 2015, Effect of mangrove bark condensed tannins (Rhizophora apiculata) as corrosion inhibitor for mild steel in simulated splash zone, J. Sci. Res. Dev., 2 (13), 59-63.

[18] Rahim, A.A., Rocca, E., Steinmetz, J., Adnan, R., and Kassim, J.N., 2004, Mangrove tannins as corrosion inhibitors in acidic medium-Study flavanoid monomers, EUROCORR 2004-European Corrosion Conference: Long Term Prediction and Modelling of Corrosion, 12-16 September 2004, Nice, France.

[19] Peres, R.S., Cassel, E., and Azambuja, D.S., 2012, Black wattle tannin as steel corrosion inhibitor, ISRN Corros., 2012, 937920.

[20] Negm, N.A., Badr, E.A., Tawfik, S.M., and El Farargy, A.F., 2014, Performance of nonionic surfactants derived from tannic acid in preventing the acidic dissolution of carbon steel, IOSR J Appl. Chem., 7 (6), 31-42.

[21] Tovar, C.T., Ortiz, Á.V., and Jaraba, L.E.G., 2015, Kinetics of adsorption in mercury removal using cassava (Manhiot esculenta) and lemon (Citrus limonum) wastes modified with citric acid, Ing. Univ., 19 (2), 283-298.

[22] Drake, L.R., and Rayson, G.D., 1996, Plant-derived materials for metal ion selective binding and preconcentration, Anal. Chem., 68 (1), 22A-27A.

[23] Pizzi, A., 1980, Tannin-based adhesives, J. Macromol. Sci., Polym. Rev., 18 (2), 247-315.

[24] Huang, X., Liao, X., and Shi, B., 2009, Hg(II) removal from aqueous solution by bayberry tanninimmobilized collagen fiber, J. Hazard. Mater., 170 (23), 1141-1148.
[25] Torres, J., Olivares, S., De La Rosa, D., Lima, L., Martínez, F., Munita, C.S., Favaro, D.I.T., 1999, Removal of mercury (II) and methyl mercury from solution by tannin adsorbents, J. Radioanal. Nucl. Chem., 240 (1), 361-365.

[26] Vázquez, G., González-Álvarez, J., Freire, S., LópezLorenzo, M., and Antorrena, G., 2002, Removal of cadmium and mercury ions from aqueous solution by sorption on treated Pinus pinaster bark: Kinetics and isotherms, Bioresour. Technol., 82 (3), 247-251.

[27] Yurtsever, M., and Şengil, İ.A., 2009, Biosorption of $\mathrm{Pb}$ (II) ions by modified quebracho tannin resin, $J$. Hazard. Mater., 163 (1), 58-64.

[28] Agarwal, H., Sharma, D., Sindhu, S.K., Tyagi, S., and Ikram, S., 2010, Removal of mercury from wastewater use of green adsorbents - A review, Electron. J. Environ. Agric. Food Chem., 9 (9), 15511558.

[29] Anirudhan, T.S., and Suchithra, P.S., 2008, Synthesis and characterization of tanninimmobilized hydrotalcite as a potential adsorbent of heavy metal ions in effluent treatments, Appl. Clay Sci., 42 (1-2), 214-223.

[30] Leme, F.P., 1990, Teoria e técnicas de tratamento de água, Rio de Janeiro: ABES, 540-564.

[31] Thakur, S.S., and Choubey, S., 2014, Use of tannin based natural coagulants for water treatment: An alternative to inorganic chemicals, Int. J. ChemTech Res., 6 (7), 3628-3634.

[32] Özacar, M.A., and Şengil, İ.A., 1997, Spectrophotometric methods for the estimation of tannins in plant tissues, Proceeding of XI, National Chemistry Congress, Van, 502.

[33] Steiner, P.R., 1989, "Tannins as Specialty Chemicals: An Overview" in Chemistry and Significance of Condensed Tannins, Eds. Hemingway, R.W., Karchesy, J.J., and Branham, S.J., Springer, Boston, 517-523.

[34] Caby, D., 2018, Oilfield Solutions, http://www.oilfield -solutions.basf.com/ev/internet/oilfield-solutions/en _GB/applications/drilling/thinners, accessed on 3 January 2018. 
[35] Bax, N.K., 2015, Waste Management and Control, CreateSpace Independent Publishing Platform, U.S., 15.

[36] Ibrahim, M.N.M., Chuah, S.B., and Cheng, P.Y., 2003, Tin-tannin-lignosulfonate complex: An improved lignosulfonate based drilling fluid thinner, Jurnal Teknologi, 38 (3), 25-32.

[37] Hussein, A.S., Ibrahim, K.I., and Abdulla, K.M., 2011, Tannin-phenol formaldehyde resins as binders for cellulosic fibers: Mechanical properties, Nat. Resour., 2 (2), 98-101.

[38] Santana, M.A.E., Baumann, M.G.D., and Conner, A.H., 1995, Resol resins prepared with tannin liquified in phenol, Holzforschung, 49 (2), 146-152.

[39] Konai, N., Raidandi, D., Pizzi, A., Girods, P., Lagel, M.C., and Kple, M., 2016, Thermogravimetric analysis of anningre tannin resin, Maderas, Cienc. Tecnol., 18 (2), 245-252.

[40] Tondi, G., 2017, Tannin-based copolymer resins: Synthesis and characterization by solid state ${ }^{13} \mathrm{C}$ NMR and FT-IR spectroscopy, Polymers, 9, 223-240.

[41] Chaieb, E., Bouyanzer, A., Hammouti, B., and Berrabah, M., 2009, Limonene as green inhibitor for steel corrosion in hydrochloric acid solutions, Acta Phys. Chim. Sin., 25 (7), 1254-1258. 